Dr Anastazja Sorkowicz, https:/ / orcid.org/0000-0001-7102-9546

Uniwersytet Ślaski w Katowicach

\title{
Nauczanie Kościoła Katolickiego o małżeństwie i rodzinie a wybrane wyzwania związane $z$ rodzicielstwem
}

\section{The teaching the Catholic Church about marriage and family versus selected parenting challenges}

https://doi.org/10.34766/ fetr.v45i1.462

\begin{abstract}
Abstrakt: Celem prezentowanego artykułu jest prześledzenie wybranych fragmentów nauczania Kościoła Katolickiego o małżeństwie i rodzinie oraz odniesienie do nich istotnych wyzwań związanych z odpowiedzialnym pełnieniem roli rodziców. Na podstawie dokonanej analizy, zarówno materiałów źródłowych, jak i opracowań, można stwierdzić, że wejście na droge sakramentalnego małżeństwa łączy się z konkretnymi zobowiązaniami zarówno małżonków wobec siebie wzajemnie, jak i wobec będących owocem ich związku dzieci. Zrozumienie istoty małżeństwa i rodziny, spokojne przyjmowanie kolejnych etapów życia małżeńskiego i rodzinnego, jako zmiany będącej bardziej szansą na nowe, aniżeli stratą oraz zaangażowanie w pracę na rzecz uczynienia małżeństwa i rodziny miejscem rozwoju wszystkich, wydają się być wyzwaniami, przed którymi stają wszyscy małżonkowie-rodzice. Koniecznym elementem codziennego życia wspólnoty rodzinnej jest przyjmowanie właściwej perspektywy relacji wewnątrzrodzinnych, ze szczególnym uwzględnieniem pierwszeństwa relacji małżeńskiej.
\end{abstract}

Słowa kluczowe: małżeństwo sakramentalne, rodzina, nauczanie Kościoła Katolickiego

Abstract: The aim of this article is to analyse selected fragments of the teaching of the Catholic Church on marriage and family and to relate them to important challenges connected with the responsible fulfilment of the role of parents. On the basis of the analysis of both source materials and studies, it may be concluded that entering into the path of sacramental marriage is connected with specific obligations of spouses towards each other and towards children who are the fruit of their union. Understanding the essence of marriage and the family, calmly accepting the successive stages of marital and family life as a change that is an opportunity for experiencing something a new rather than a loss, and engaging in the work of making marriage and the family a place of development for all, seem to be challenges facing all spouses-parents. A necessary part of the daily life of the family community is to take a proper perspective of the intra-family relationship, with particular attention to the primacy of the marital relationship.

Keywords: sacramental marriage, family, teaching of the Catholic Church

\section{Wprowadzenie}

Małżeństwo oraz zbudowana na jego podstawie rodzina to instytucje społeczne występujące $\mathrm{w}$ różnych kulturach. Pomimo istnienia różnic $\mathrm{w}$ pojmowaniu istoty tych instytucji, zawsze mają charakter publiczny oraz podlegają prawom i zwyczajom wspólnoty (Adamski, 2002, Aszkiełowicz, 2012). Jeśli chodzi o małżeństwo, to podkreśla się, że „zawsze i wszędzie odróżnia się związki nazywane małżeńskimi od innych form współżycia 
ludzkiego" (Aszkiełowicz, 2012, s. 168). Również rodzina zwykle cieszy się konkretnymi przywilejami oraz zainteresowaniem społecznym. Osoby wierzące w Boga mają świadomość istnienia wymiaru religijnego tych podstawowych wspólnot międzyludzkich. Istnieją różnice $\mathrm{w}$ pojmowaniu zarówno istoty, jak i funkcji, zarówno małżeństwa, jak i rodziny przez poszczególne religie. Analiza porównawcza wskazanych zjawisk, przeprowadzona w świetle różnych religii czy kultur, nie stanowi jednak przedmiotu niniejszych rozważań.

Celem prezentowanego artykułu jest bowiem podjęcie próby przedstawienia wybranych elementów nauczania Kościoła Katolickiego o małżeństwie i rodzinie oraz odniesienie do nich istotnych wyzwań związanych z pełnieniem roli małżonków i rodziców. Rozważania zaprezentowane zostaną z perspektywy pedagoga. Analizie zostaną poddane wybrane dokumenty Kościoła Katolickiego oraz opracowania podejmujące wskazaną tematykę. U podstaw prowadzonych dociekań leży przekonanie wyrażone przez Janusza Mariańskiego, że „prawda o małżeństwie i rodzinie wynika z transcendentnego obrazu człowieka i jego natury, a instytucja małżeńska istniała w zamyśle Bożym od chwili stworzenia" (Mariański, 2009, s. 245). Warto podkreślić, że dla człowieka wierzącego czymś naturalnym jest odnoszenie do Boga - Stwórcy istotnych wartości życia człowieka, za jakie należy uznać małżeństwo, rodzinę i wszystkie sprawy związane z tymi przestrzeniami (Meissner, 2017).

\section{Małżeństwo zawarte w Kościele Katolickim}

Małżeństwo zawierane w Kościele Katolickim uznawane jest za instytucję, której twórcą i głównym „ustawodawcą” jest sam Bóg. W społeczności osób wierzących uznaje się ogromne znaczenie związku małżeńskiego dla szczęścia osobistego i wspólnotowego (Gaudium et spes, 47). Małżeństwo jest jedyną relacją międzyludzką, która w Kościele Katolickim została podniesiona do godności sakramentu. Jest to sakrament, który nie jest udzielany przez kapłana, a przez samych narzeczonych. W literaturze przedmiotu podkreśla się doniosłość i głębię sakramentu małżeństwa, który przenika „aż do samego dna” różnice płciowe oraz „przepromienia łaską cielesność i seksualność małżonków” (Drążek, 2009, s. 85). Żaden inny związek międzyludzki nie posiada tak wielkiej rangi jak małżeństwo zawierane w kościele. Osoby decydujące się dobrowolnie i bez żadnego przymusu zawrzeć związek małżeński tworzą nierozerwalną wspólnotę życia „ustanawianą przez przymierze i zgodę małżonków” i ukierunkowaną na dobro małżonków, prokreację i wychowanie dzieci (Katechizm Kościoła Katolickiego, 2249; Sztychmiler, 1999, s. 223). Wypowiedziane przez szafarzy sakramentu małżeństwa słowa: „biorę ciebie za żonę” oraz „biorę ciebie za męża” stanowią podstawę nierozerwalnej wspólnoty (Katechizm Kościoła Katolickiego, 1627). Małżonkowie katoliccy korzystają z łaski sakramentu małżeństwa dla „udoskonalenia miłości” oraz „umocnienia jedności” (Katechizm Kościoła Katolickiego, 1641). Z chwilą 
zawarcia związku małżeńskiego powstaje nowa struktura, „nowa jedność”, czyli diada małżeńska, która nie jest tożsama z prostą sumą dwojga osób. Małżeństwo jest wspólnotą kobiety i mężczyzny „w której nie ma zysków i strat osobnych, a wszystko liczy się razem” (Braun-Gałkowska, 2009, s. 141).

Zadaniem obojga małżonków, za którego wypełnienie $\mathrm{w}$ równym stopniu odpowiedzialni są mężczyzna i kobieta, jest wzajemna pomoc, świadczona $\mathrm{w}$ ramach budowania wspólnoty osób. Kościół uznaje, że człowiek został stworzony na obraz i podobieństwo Boże. Został stworzony jako mężczyzna albo jako kobieta. Istotnym jest uznanie, że oboje nie są „niekompletnymi częściami”, ale każde z nich stanowi wartość samą w sobie. „(...) Płeć służy także zaspokojeniu potrzeby społecznej człowieka. Jest po to, aby znaleźć i kochać istotę równą sobie i dzielić z nią życie" (Zwoliński, 2004, s. 183). W Katechizmie Kościoła Katolickiego znajdują się słowa: „Mężczyzna i kobieta, stworzeni razem, są chciani przez Boga jako jedno dla drugiego” (Katechizm Kościoła Katolickiego, 371). Ukoronowaniem tego bycia wzajemnie dla siebie jest przekazanie życia dzieciom, zgodnie z Boskim nakazem: „Bądźcie płodni i rozmnażajcie się, abyście zaludnili ziemię” $(\operatorname{Rdz} 1,28)$. Przekazanie życia dzieciom stanowi jeden $\mathrm{z}$ istotnych celów małżeństwa zawieranego w kościele. Warto jednak zaznaczyć, że nie jest to jedyny cel małżeństwa katolickiego. Małżeństwo bowiem stanowi szczególne miejsce, w którym oboje: mężczyzna i kobieta, żyją dla siebie wzajemnie. Kościół, przypominając słowa Księgi Rodzaju: „Nie jest dobrze, żeby mężczyzna był sam” (Rdz 2,18) zwraca uwagę na społeczną naturę człowieka, który realizuje się przede wszystkim poprzez bycie w relacji z innymi ludźmi. Małżeństwo zbudowane na wzajemnej miłości stanowi jedną z najdoskonalszych wspólnot ludzkich, ponieważ przedstawia obraz najwyższej formy zjednoczenia międzyosobowego, na płaszczyźnie wiary porównywaną do miłości, jaką Bóg obdarowuje człowieka (Katechizm Kościoła Katolickiego, 1604). Podstawową przyczyną zaistnienia małżeństwa jest wzajemna miłość, która jest „potężna jak śmierć” i której „wody wielkie nie zdołają ugasić” (Pnp 8, 6-7). Dzięki wzajemnej komplementarności małżonkowie są $\mathrm{w}$ stanie zbudować najbliższą i najbardziej intymną więź, jaka może istnieć pomiędzy ludźmi. Nauczanie Kościoła przypomina biblijne słowa: „już nie są dwoje, ale jedno" (Mt 19, 6). To stawanie się jednym ciałem można rozumieć w każdym wymiarze życia człowieka. Małżeństwo sakramentalne jest bowiem związkiem totalnym, nastawionym na budowanie pełnej wspólnoty, komunii osób. Dochodzi do połączenia się $\mathrm{w}$ jedno całego życia dwóch osób. W tym miejscu słusznym wydaje się podkreślenie, że prawdziwa wspólnota małżeńska nigdy nie oznacza naruszenia indywidualności biorących $\mathrm{w}$ niej udział osób, ale jej istnienie jest wyrazem przekroczenia egoizmu i samotności oraz chęci wzajemnej pomocy (Skrzypczak, 2018, s. 278; Półtawska, 2018, s. 161). Każde z małżonków pozostaje sobą a jednocześnie oddaje siebie samego na służbę współmałżonkowi, z założeniem, że odtąd wszystkie sprawy mają wspólne. Mąż staje się dla żony najbliższą osobą, a żona jest dla męża najważniejszym 
człowiekiem wybranym spośród wielu innych kobiet. Nie ma rywalizacji, a jedynie wspólna dbałość o dobro obojga.

Życie w sakramentalnym małżeństwie zakłada konieczność wzajemnego poddania się małżonków, którzy żyją jedno dla drugiego, którzy sobie wzajemnie służą. Realizują w ten sposób biblijny nakaz: „Bądźcie sobie wzajemnie poddani” (Ef 5,21). Dobrze się dzieje, jeśli obojgu małżonkom towarzyszy spokojne przeświadczenie o trwaniu w wyjątkowej wspólnocie z drugim człowiekiem, w „nienaruszalnej jedności życia” (Katechizm Kościoła Katolickiego, 1605). Należy podkreślić, że każde z małżonków jest zarazem kompletną osobą i istotną częścią „jedności dwojga” uzupełniających się wzajemnie osób (Katechizm Kościoła Katolickiego, 372). Chociaż mają do spełnienia odmienne role, to jednak „ich osoby są $\mathrm{w}$ pełni równe $\mathrm{w}$ swoim darze wzajemnym i w prawie wzrastania w godności ludzkiej i synostwie Bożym" (Zwoliński, 2004, s. 183).

Nauczanie Kościoła Katolickiego idzie w kierunku myślenia o małżeństwie jako o jedynym w swoim rodzaju związku, polegającym na całkowitym zjednoczeniu dwóch osób: "stają się jednym ciałem” (Rdz 2, 24). Powyższe wyrażenie bywa interpretowane jako obrazowe określenie zjednoczenia seksualnego, będącego istotnym elementem wspólnego życia. Takie wyjaśnienie wydaje się jednak zbyt ubogie. Dlatego warto zwrócić uwagę na starotestamentalne znaczenie wyrażenia ,jedno ciało". W literaturze przedmiotu zwraca się uwagę, że wspomniana fraza oznacza całego człowieka, całą jego istotę, czyli "osobę”. Powstająca wspólnota osób, której istnienie definiuje kategoria wzajemnego daru, polega na "zupełnym stopieniu się pragnień i uczuć oraz całego życia obojga”, na "pełnej jedności duchowo-cielesnej, która można nazwać osobq matżeńska" (Grześkowiak, 1993, s. 86). Oznacza to „nienaruszalną jedność ich życia”, zgodnie z pierwotnym zamysłem Stwórcy (Katechizm Kościoła Katolickiego, 1605). Osobowa wspólnota małżonków obejmuje całe ich życie (Katechizm Kościoła Katolickiego, 1644), a sama płciowość ma swoje znaczenie nie tylko biologiczne, ale dotyczy również „samej wewnętrznej istoty osoby ludzkiej jako takiej. Urzeczywistnia się ona w sposób prawdziwie ludzki tylko wtedy, gdy stanowi integralną część miłości, którą mężczyzna i kobieta łączą się ze sobą aż do śmierci" (Katechizm Kościoła Katolickiego, 2361). Jak zwraca uwagę Andrzej Zwoliński „płeć służy (...) zaspokojeniu potrzeby społecznej człowieka. Jest po to, aby znaleźć i kochać osobę równą sobie i dzielić z nią życie" (Zwoliński, 2004, s. 183). W Katechizmie Kościoła Katolickiego małżeństwo sakramentalne bywa również ujmowane $\mathrm{w}$ kategoriach instytucji pomagającej grzesznemu człowiekowi „przezwyciężyć zamknięcie się w sobie, egoizm, szukanie własnych przyjemności” (Katechizm Kościoła Katolickiego, 1609) oraz „otworzyć się na drugiego człowieka, na wzajemną pomoc i dar z siebie” (Katechizm Kościoła Katolickiego, 1609). Opowiedziana w Nowym Testamencie sytuacja mająca miejsce na weselu w Kanie Galilejskiej, sama obecność Chrystusa na uczcie, stanowi dodatkową legitymizację związku 
kobiety i mężczyzny. Jest znakiem, poświadczeniem, że małżeństwo jest czymś dobrym (Katechizm Kościoła Katolickiego, 1613).

Wszelkie rozważania dotyczące małżeństwa zawieranego w Kościele Katolickim muszą zostać poprzedzone uznaniem prawdy o pochodzeniu i przeznaczeniu człowieka, czyli tego, iż człowiek został stworzony na obraz i podobieństwo Boże jako mężczyzna i kobieta. Wanda Półtawska podkreśla za Karolem Wojtyłą, iż „wszystkie problemy indywidualne człowieka rozwiązuje genealogia divina - Boże pochodzenie człowieka" (Półtawska, 2018, s. 113). Katechizm Kościoła Katolickiego uczy, że „zróżnicowanie i komplementarność fizyczna, moralna i duchowa są ukierunkowane na dobro małżeństwa i rozwój życia rodzinnego" (Katechizm Kościoła Katolickiego, 2333). Warto zauważyć, że współcześnie niektóre prądy kulturowe i polityczne dążą do zatarcia i pomniejszenia wpisanych w naturę ludzką różnic między płciami, traktując je jako wytwór kultury. Kościół Katolicki podkreśla równość kobiet i mężczyzn, ale równocześnie zwraca uwagę na powołanie przedstawicieli obu płci do „wzajemności i komplementarności, do współpracy i jedności" (Mariański, 2009, s. 246). Na marginesie prowadzonych rozważań należy zaznaczyć, że w Kościele nie może być mowy o traktowaniu na równi małżeństwa i innych związków międzyludzkich. Doktryna wiary nie może zostać zmieniona przez żadnego człowieka. Ważnie i godnie zawarte małżeństwo zawsze będzie w Kościele kategorią cieszącą się konkretnymi przywilejami. Żadne próby uznawania, nazywania małżeństwem związków innych od małżeństwa pomiędzy jedną kobietą i jednym mężczyzną nie zmienią odwiecznego, opartego na Objawieniu, nauczania Kościoła.

Jednym z podstawowych warunków zaistnienia wspomnianej wyżej „osoby małżeńskiej" jest opuszczenie rodziny pochodzenia. Mamy tu do czynienia z kategorycznym stwierdzeniem: „opuści człowiek ojca i matkę i złączy się ze swoją żoną, i będą oboje jednym ciałem" (Mt 19, 5). Warto zaznaczyć, że powyższe słowa w takim samym stopniu odnoszą się do człowieka - kobiety, która zobowiązana jest do zostawienia swoich rodziców i zbudowania nowej jedności z mężem. Zwrócenie uwagi na ten stanowczy nakaz odnoszący się do osób zawierających małżeństwo sakramentalne wydaje się szczególnie ważne biorąc pod uwagę problematykę niniejszej pracy. Odejście z domu rodzinnego stanowi bowiem ważny krok na drodze ku dojrzałości osobowej człowieka. Należy zwrócić uwagę, że zawarcie małżeństwa sakramentalnego zarezerwowane jest dla osób dojrzałych, zdolnych do w pełni samodzielnego życia. Zdaniem Marii Ryś „,rodzina prawidłowa powstaje na bazie kochającego się związku małżeńskiego dwóch osób o dojrzałej osobowości" (Ryś, 2011, s. 179). Niewłaściwa relacja z rodzicami kładzie się cieniem najpierw na małżeństwie, a następnie na całej nowej rodzinie. Zbudowanie nowej jakości, całkowitej i jedynej w swoim rodzaju relacji ze współmałżonkiem wymaga tego, aby oboje małżonkowie w sposób świadomy podjęli decyzję o odejściu od swoich rodzin pochodzenia. Przy czym zdecydowanie ważniejsze aniżeli opuszczenie domu rodzinnego w sensie dosłownym, 
fizycznym, wydaje się dojrzałe wyjście z rodziny pochodzenia w znaczeniu mentalnym, które odbywa się stopniowo w miarę dorastania dziecka.

\section{Rodzicielstwo na fundamencie sakramentu małżeństwa}

Jednym z podstawowych przymiotów małżeństwa sakramentalnego jest płodność. Ojciec Święty Paweł VI w Encyklice Humanae vitae podkreślał konieczność współpracy obojga małżonków „w wydawaniu na świat i wychowywaniu nowych ludzi” (Paweł VI, 1968, n 8). Dlatego małżonkowie poprzez wzajemne oddanie się sobie, im tylko właściwe i wyłączne, dążą do takiej wspólnoty osób, aby doskonaląc się w niej wzajemnie, współpracować równocześnie z Bogiem w wydawaniu na świat i wychowywaniu nowych ludzi. „Miłość małżeńska, którą Bóg błogosławi, jest przeznaczona do tego, by była płodna i urzeczywistniała się we wspólnym dziele zachowywania stworzenia" (Katechizm Kościoła Katolickiego, 1604). „Konstytucja duszpasterska o Kościele w świecie współczesnym Gaudium et spes" mówi wprost: „Małżeństwo i miłość małżeńska z natury swej skierowane są ku płodzeniu i wychowywaniu potomstwa. Dzieci też są najcenniejszym darem małżeństwa i rodzicom przynoszą najwięcej dobra" (Gaudium et spes, 50). Ludzkie rodzicielstwo stanowi widoczny znak współpracy ludzi ze Stwórcą, ale nie jest powołaniem powszechnym, ogólnoludzkim. Dotyczy bowiem tylko małżonków (Półtawska, 2009; Łużyński, 2008). Zobowiązanie do rodzicielstwa jest tak istotne, że znajduje się w formule zawierania sakramentu małżeństwa. Decyzja o przyjęciu dziecka, które może się pojawić jako owoc intymnej relacji małżeńskiej, wyrażana jest podczas ślubowania narzeczonych. Pozytywna odpowiedź na zadane przez celebransa pytanie: „Czy chcecie z miłością przyjąć i po katolicku wychować potomstwo, którym was Bóg obdarzy?" (Obrzędy sakramentu małżeństwa, 1996, s. 29), stanowi nie tylko wyraz woli nupturientów, ale również warunek konieczny do uznania małżeństwa za ważne. Wykluczanie dzieci jest równoznaczne z brakiem świadomości, czym naprawdę jest małżeństwo sakramentalne. Rodzicielstwo zatem jest dla małżonków katolickich przede wszystkim źródłem radości, której towarzyszy świadomość podjęcia współdziałania „z dziełem Stwórcy" (Katechizm Kościoła Katolickiego, 372). W Katechizmie można znaleźć następujące słowa: „Dziecko nie przychodzi z zewnątrz jako dodane do wzajemnej miłości małżonków; wyłania się w samym centrum tego wzajemnego daru, którego jest owocem i wypełnieniem" (Katechizm Kościoła Katolickiego, 2366).

Dla małżonków zawierających ślub w Kościele Katolickim czymś najzupełniej normalnym powinno więc być przyjęcie dziecka, będącego „największym darem małżeństwa" (Katechizm Kościoła Katolickiego, 2378). Ze strony rodziców konieczne jest uznanie każdego swojego dziecka za dziecko Boże oraz okazywanie mu szacunku jako osobie ludzkiej (Katechizm Kościoła Katolickiego, 2222). Katechizm podkreśla, że „dziecko 
nie jest czymś należnym", że nigdy nie wolno traktować go jako przedmiotu własności. Ze względu na współczesne dyskusje dotyczące kwestii najbardziej zasadniczych należy podkreślić, że Kościół sprzeciwia się używaniu sformułowania "prawo do dziecka” (Katechizm Kościoła Katolickiego, 2378). W świecie osób nie może być mowy o żądaniu posiadania drugiego człowieka, ponieważ żaden człowiek, na żadnym etapie swojego życia nie może być traktowany w kategoriach rzeczy. Od poczęcia do śmierci każdy człowiek stanowi przede wszystkim osobę, niepowtarzalną wartość, niepodlegającą żadnej kalkulacji. Wanda Półtawska stwierdza stanowczo: „Jesteś na szczycie stworzenia. Powyżej człowieka nie ma nic więcej na ziemi. (...) Wielkości człowieka nie da się niczym zmierzyć. I stąd nie można mówić, że czyjeś życie jest nieważne. Każde życie ludzkie jest ważne, bo każdy człowiek jest ważny" (Półtawska, 2018, s. 123-124).

Zatem człowiek-dziecko, jako "korona stworzenia i adoptowane dziecko Boże" (Majdański, 2001, s. 66), wymaga od samego początku specjalnego, godnego traktowania. Jak wcześniej wspomniano, żadne dziecko nie jest na żadnym etapie swojego życia własnością swoich rodziców. Nawet w sytuacji najściślejszego zjednoczenia fizycznego dwóch osób: matki i dziecka, w okresie prenatalnym, dziecko jest osobnym człowiekiem, który będzie szedł swoją własną drogą. To dziecko od początku swego istnienia jest podmiotem praw. „Instrukcja o szacunku dla rodzącego się życia ludzkiego i o godności jego przekazywania Donum vitae" określa w sposób jasny, iż dziecko ma prawo do tego, aby „być owocem właściwego aktu miłości małżeńskiej swoich rodziców, i by również mieć prawo do szacunku jako osoba od chwili swego poczęcia" (Kongregacja Nauki Wiary, Donum vitae, n. 8). Niezależnie więc od stanu świadomości czy stanu zdrowia, dziecko zawsze pozostaje kimś, kto został „na chwilę” podarowany małżonkom, jako widzialny znak ich wzajemnej miłości, jako „kontynuacja rodziców” (Augustyn, 2001, s. 97). „Gdy z małżeńskiej jedności dwojga rodzi się nowy człowiek, to przynosi on z sobą na świat szczególny obraz i podobieństwo Boga samego: w biologię rodzenia wpisana jest genealogia osoby" (Jeżyna, 2008, s.128).

Pojawienie się na świecie dziecka, owocu miłości małżeńskiej, stanowi dla jego rodziców ogromne wyzwanie. Powierzenie rodzicom dziecka jest przez wierzących traktowane jako wyraz szczególnego zaufania Stwórcy wobec stworzenia oraz łączy się z ogromną odpowiedzialnością (Bełch, 2020). Warto zwrócić uwagę, że odpowiedzialność rodzicielska zaczyna się na długo przed poczęciem dziecka. Małżonkowie-rodzice zobowiązani są do założenia takiego ogniska domowego, „w którym panuje czułość, przebaczenie, szacunek, wierność i bezinteresowna służba” (Katechizm Kościoła Katolickiego, 2223). Oczywistym więc jest zawieranie małżeństwa przez osoby w pełni dojrzałe, mające świadomość zarówno istoty sakramentu, jak też jego naturalnych konsekwencji. Tylko osoby w pełni odpowiedzialne „za swoje myśli, uczucia i działanie” (Błasiak, 2012, s. 326) mają szansę stworzyć udane małżeństwo i rodzinę. Podstawowym 
zadaniem małżonków-rodziców, w prosty sposób wynikającym z faktu powołania do życia nowego człowieka, jest wychowanie dziecka. Rodzice zobowiązani są do zbudowania domu, który stałby się „miejscem kształtowania cnót” (Katechizm Kościoła Katolickiego, 2223). Działania rodzicielskie winny prowadzić dzieci do "prawdziwej wolności”, czyli do „nauczenia się wyrzeczenia, zdrowego osądu, panowania nad sobą" (Katechizm Kościoła Katolickiego, 2223). W nauczaniu Kościoła Katolickiego podkreśla się konieczność komplementarnego wychowania dzieci, które powinno „zmierzać do kształtowania osoby ludzkiej, mając na uwadze jej wieczne zbawienie, a także dobro społeczeństwa, tak aby, gdy dziecko dorośnie, mogło podjąć obowiązki społeczne. Głównym zadaniem rodziców jest kształtowanie $\mathrm{w}$ dzieciach poczucia sprawiedliwości, która prowadzi do poszanowania godności każdego człowieka, a także poczucia prawdziwej miłości, jako podstawy troski i bezinteresownej służby wobec drugich" (Bełch, 2020, s. 201). Wychowanie bywa utożsamiane z rodzeniem w znaczeniu duchowym (Łużyński, 2008), stanowi z jednej strony prawo i obowiązek rodziców, a z drugiej jest prawem każdego rodzącego się dziecka. Każde dziecko ma prawo do najkorzystniejszych warunków wychowania (Łużyński, 2008). Podstawowym środkiem wychowawczym $\mathrm{w}$ rodzinie powinien być przykład życia rodziców, w tym również umiejętność przyznania się do własnych błędów (Katechizm Kościoła Katolickiego, 2223). W tym kontekście niezwykle ważne wydaje się zwrócenie uwagi na konieczność permanentnego namysłu nad istotą człowieczeństwa, czyli również nad naturalną skłonnością osoby ludzkiej zarówno w stronę dobra, jak i w stronę zła. Dobrze, jeśli małżonkom-rodzicom towarzyszy świadomość własnej omylności, która jednak nie powoduje poczucia klęski, jeśli potrafią zaakceptować swoją własną wartość i godność bez poczucia dumy, a także kiedy potrafią pokonywać trudności wynikające zarówno z zewnętrznych sytuacji, jak i wypływających z wnętrza człowieka (Ryś, 1998).

Ludzkie rodzicielstwo od samego początku wymaga od obojga rodziców przede wszystkim otwarcia na zmiany, które stają się udziałem wszystkich, którym dana jest możliwość towarzyszenia $\mathrm{w}$ rozwoju młodemu człowiekowi. Ze względu na oczywistą nieporadność przychodzącego na świat dziecka, początkowe zaangażowanie rodziców w zapewnienie dziecku tego wszystkiego, czego ono potrzebuje, jest ogromne. Konieczność zapewnienia małemu człowiekowi właściwej opieki zmienia relację małżeńską. Oboje rodzice $\mathrm{w}$ równym stopniu powołani są do podjęcia trudu wychowania własnego dziecka. Właściwe ułożenie wzajemnych relacji małżeńskich po urodzeniu dziecka staje się równie ważnym zadaniem, jak opieka nad dzieckiem. Jako że mamy do czynienia z ogromną zmianą w życiu, należy wziąć pod uwagę ewentualność kryzysu, który może nastąpić w relacji małżeńskiej. Dlatego tym bardziej istotne wydaje się zatroszczenie się o relację z osobą, z którą został zawarty sakrament małżeństwa. W zdrowym małżeństwie nie ma wątpliwości, która relacja jest najważniejsza i stanowi bazę dla wszystkich innych, które powstają z czasem, w miarę kolejnych zmian zachodzących w strukturze rodziny. Nigdy, na 
żadnym etapie życia rodziny, nie może być mowy o naruszeniu tej podstawowej zasady prymatu więzi małżeńskiej nad rodzicielską. Również wszelkie inne okoliczności uznawane za szczególnie trudne nie stanowią usprawiedliwienia dla „ucieczki w rodzicielstwo". Oczywistym jest, że wymagania związane z przeżywaniem poszczególnych etapów życia małżeństwa i rodziny implikują konkretne zachowania. Zawsze jednak małżonkomrodzicom powinno towarzyszyć przeświadczenie o pierwszeństwie roli małżeńskiej. Wkrótce po narodzinach dziecka można się spotkać z takim zaabsorbowaniem czynnościami opiekuńczymi, których wymaga bezbronność i bezradność małego człowieka, że nie ma już miejsca na podstawową i nadal najważniejszą relację. Kobieta, która stała się matką, może tak bardzo zaangażować się w życie swego dziecka, że niejako zapomni o relacji z mężem, o rozłożonym na całe życie zadaniu budowania jedności, "osoby małżeńskiej” z mężem. Pozbawiona należnego miejsca relacja ze współmałżonkiem może zacząć tracić na znaczeniu w życiu obojga małżonków. Konsekwencje takiego stanu rzeczy mogą być bardzo poważne. Jeśli ta sytuacja nie zostanie w umiejętny sposób naprawiona, problemy będą się pogłębiać. Zdaniem Marii Braun-Gałkowskiej „rodzice powinni mieć coś, co ich łączy niezależnie od dzieci. Powinni w okresie wielkiego zaabsorbowania nimi i przemęczenia pracą dla nich, nie zapominać o narzeczeńskim chodzeniu ze sobq, choćby czasami, i o wspólnych przyjemnościach. Powinni rozmawiać ze sobą także o innych sprawach niż dzieci i kłopoty materialne(...), gdyż w przeciwnym razie z czasem nic nie będzie ich łączyć. Trzeba starać się zachować pewien dystans w stosunku do bieżących kłopotów i świadomie starać się opanowywać powszechną tendencję do pośpiechu. Dzieci są małe bardzo krótko, warto przeżyć wspólnie radość z ich posiadania, a nie tylko czekać, aż podrosną. (...) Dlatego, choć dzieci są najbardziej naturalnym wspólnym celem działania, nie powinny stać się jedyną wartością łączącą rodziców" (Braun-Gałkowska, 2009, s. 145).

Podsumowując tę część rozważań należy podkreślić, że celebracja związku z dzieckiem, kosztem więzi ze współmałżonkiem, nie tylko narusza fundament rodziny, jakim jest małżeństwo, ale szkodzi wszystkim pozostałym relacjom i zagraża rozwojowi wszystkich członków rodziny, niezależnie od fazy życia, w której się znajduje. Wydaje się jednak, że wspomniana sytuacja jest szczególnie niebezpieczna na etapie dorastania i dorosłości dziecka.

\section{Dorastające i dorosłe dziecko w rodzinie}

Nauczanie Kościoła Katolickiego definiuje rodzinę jako złożoną z osób "uprzywilejowaną wspólnotę”, której zadaniem jest „wspólna wymiana myśli pomiędzy małżonkami oraz troskliwe współdziałanie rodziców w wychowywaniu dzieci" (Katechizm Kościoła Katolickiego, 2206). Uznanie rodziny za wspólnotę wymaga od rodziców pracy na rzecz nauczenia dzieci: „,budowania więzi międzyludzkich, szacunku dla samego siebie i dla 
każdego człowieka, tolerancji dla jego inności, poszanowania odmiennych poglądów, postaw, umiejętności właściwej komunikacji, rozwiązywania problemów, cenienia istotnych wartości, zaspokojenia potrzeb miłości, życzliwości" (Ryś, 1998, s. 35). Powszechnie uznaje się rodzinę za miejsce, które ma duży wpływ na rozwój człowieka, ponieważ „jest chronologicznie pierwszym środowiskiem wpływu wychowawczego i miejscem, w którym gromadzone są pierwsze doświadczenia związane z własną osobą, uczestnictwem w świecie i relacją z otoczeniem zewnętrznym" (Opozda, 2012, s. 25).

Jako podstawowe środowisko życia rodzina staje się miejscem wzajemnej troski i szacunku. Zarówno czwarte przykazanie Dekalogu, jak i Katechizm Kościoła Katolickiego zwracają uwagę na potrzebę okazywania przez dzieci czci rodzicom tylko i wyłącznie ze względu na wdzięczność za dar życia. „Szacunek dla rodziców (...) wynika z wdzięczności wobec tych, którzy przez dar życia, swoją miłość i pracę wydali na świat dzieci i pozwolili im wzrastać w latach, w mądrości i w łasce" (Katechizm Kościoła Katolickiego, 2215). Dodatkowo czwarte przykazanie, jako jedyne, związane jest z konkretną obietnicą, skierowana w stronę tych osób, które go przestrzegają: „długie życie i powodzenie w życiu ziemskim". Obowiązek okazywania szacunku wobec rodziców wydaje się czymś zupełnie oczywistym, wręcz bezdyskusyjnym. Kolejny kanon Katechizmu zawiera w pewnym sensie wzmocnienie nakazu czci wobec rodziców i dopowiada obowiązek posłuszeństwa. $Z$ tego ostatniego zwalnia jedynie "przekonanie w sumieniu”, że bycie posłusznym konkretnemu poleceniu byłoby rzeczą moralnie złą (Katechizm Kościoła Katolickiego, 2217).

Niezwykle istotną kwestią, na którą zwraca uwagę nauczanie Kościoła Katolickiego, jest podkreślenie konieczności podążania rodziców za dzieckiem w miarę jego rozwoju, którzy przecież „wychowują (...) swoje dzieci do wypełniania prawa Bożego, ukazując samych siebie jako posłusznych woli Ojca niebieskiego" (Katechizm Kościoła Katolickiego, 2222). Katechizm zwraca uwagę na to, że w okresie dzieciństwa rodzice okazują szacunek i życzliwość swoim dzieciom przede wszystkim poprzez troskę i uwagę, z jaką wychowują swoje dzieci oraz „zaradzanie ich potrzebom materialnym i duchowym” (Katechizm Kościoła Katolickiego, 2228). Natomiast wraz z dorastaniem dzieci coraz większego znaczenia nabiera wychowywanie dzieci do „prawidłowego używania rozumu i wolności” (Katechizm Kościoła Katolickiego, 2228). Adolescencja jest tym okresem życia człowieka, który uznawany jest za trudny patrząc z perspektywy osób najbliższych, towarzyszących na co dzień osobie dorastającej. Zachodzące intensywne zmiany w sferze biologicznej, psychologicznej i społecznej powodują, że niektórzy określają ten okres w życiu człowieka mianem powtórnych narodzin. Często osoby z najbliższego otoczenia nastolatka mówią, że go nie poznają, oburzają się na jego trudne zachowania. Dorastanie jest również tym okresem, kiedy młody człowiek dokonuje wyboru swoje drogi życiowej. Nauczanie Kościoła Katolickiego dobitnie podkreśla, że „dorastające dzieci mają obowiązek i prawo wybrać zawód i stan życia" (Katechizm Kościoła Katolickiego, 2230). Rola rodziców w tym czasie 
polega z jednej strony na nie ograniczaniu swoich dzieci „ani w wyborze zawodu, ani wyborze współmałżonka" (Katechizm Kościoła Katolickiego, 2230), a z drugiej na pomaganiu dzieciom „przez mądre rady, zwłaszcza wtedy gdy dzieci mają zamiar założyć rodzinę" (Katechizm Kościoła Katolickiego, 2230). Katechizm zwraca uwagę na delikatność rodziców, jako ten element ich postawy, który jest najwłaściwszy i szczególnie potrzebny na tym etapie rozwoju dziecka. Wydaje się ważne, aby rodzice w okresie adolescencji swojego dziecka nie zmarnowali czasu, nie podejmowali działań, które będą zakłócały prawidłowy rozwój młodego człowieka. Dorastający człowiek powinien mieć możliwość przejmowania steru własnego życia, czyli wypełniania nowych zadań życiowych „w zaufaniu do swoich rodziców, chętnie prosząc ich o opinie oraz rady i przyjmując je od nich” (Katechizm Kościoła Katolickiego, 2230). Udzielanie rad nie może być jednak równoznaczne z oczekiwaniem pełnego dostosowania się dziecka do propozycji rodziców.

W literaturze przedmiotu zwraca się uwagę, że w okresie dorastania dziecka rodzice mierzą się z wyzwaniami związanymi z autonomią i niezależnością dzieci, że „niezbędna staje się restrukturyzacja procesów interakcji, prowadząca do zwiększenia niezależności nastolatków (Łukasiewicz, Pawelec, 2012, s. 94). Bycie w rodzinie powinno pomóc dziecku w ukształtowaniu jego poczucia godności osobistej oraz chęci rozwoju zgodnie z własnymi możliwościami (Ryś, 1998).

Papież Franciszek zwracając się do rodziców pisze, że „liczy się przede wszystkim to, aby zrodzić $\mathrm{w}$ dziecku z wielką miłością procesy dojrzewania w jego wolności, uczeniu się, kompleksowym rozwoju, pielęgnowaniu prawdziwej autonomii" (Franciszek, 2016, 261). Dodatkowo warto wziąć pod uwage to, że każdy człowiek zawsze jest dla otoczenia, również tego najbliższego, tajemnicą. Nikt, również rodzice, nie mają wszystkich informacji o dziecku, nie wiedzą, do czego zostało powołane zarówno $\mathrm{w}$ sensie stanu życia, jak i wykonywanej profesji. Osoby wierzące mają świadomość tego, że ich dziecko musi samo odczytać swoje powołanie, a ich rola polega bardziej na towarzyszeniu, byciu blisko, na „dyskretnej obecności” (Derdziuk, 2008, s. 159) aniżeli na prowadzeniu dziecka „za rękę”. Celem wysiłków wychowawczych rodziców jest „kształtowanie w dziecku zdolności do dokonywania samodzielnych wyborów i dawanie mu wolności, przez którą może ono zasmakować konsekwencji podejmowanych działań" (tamże, s. 159). Każdy rodzaj wychowania, a wychowanie rodzinne w szczególności, jest działalnością obliczoną na pożegnanie, na dojrzałe odejście dziecka. Należy więc tak postępować, „aby dziecko mogło możliwie przygotowane na koniec odejść w swoją samodzielność i swoją dojrzałość, na własne życie, rolę i spełnienie; (...) na założenie własnej szczęśliwej rodziny, na realizację swojej własnej miłości do innych i na własną samorealizację" (Homplewicz, 2000, s. 77).

W nauczaniu Kościoła podkreśla się obowiązek rodziców stworzenia takiej atmosfery rodzinnej, która byłaby przepojona „miłością i szacunkiem do Boga i ludzi”, a tym samym „sprzyjała całemu osobistemu i społecznemu wychowaniu dzieci” (Gravissimum 
educationis, 3). W literaturze pedagogicznej również zwraca się uwagę na znaczenie atmosfery panującej w rodzinie dla powodzenia procesu wychowania (por. np. Wilk, 2016, s. 69-73). Jeśli rodzina jest miejscem „szczerości i wolności, dzieci ufnie powierzają rodzicom swoje sprawy i oczekują od nich rady. Jeśli natomiast brak szacunku i życzliwości, następuje zamknięcie, utrudniające wszelki dialog" (Derdziuk, 2008, s. 158). Podkreśla się, że najskuteczniejszym środkiem pomagającym obydwu stronom przejście przez trudny okres dojrzewania, jest „zasada otwartych drzwi”. Polega ona na stworzeniu wewnątrz domu terenu swobodnych dyskusji (Sujak, 2009, s. 280). Elżbieta Sujak zwraca również uwagę na konieczność zachowania przez rodziców poczucia, że „nie dzieje się nic sprzecznego z prawami rozwoju osobowości dorastających młodych” (tamże).

Miłość do dziecka na każdym etapie jego rozwoju wymaga bezinteresowności. Wydaje się, że w przypadku rodziców dorosłych i dorastających dzieci powyższe stwierdzenie nabiera szczególnego znaczenia. $W$ okresie dorastania dziecka rodzice powinni z jeszcze większą czujnością pilnować samych siebie, swoich słów i czynów, żeby nie stworzyć fałszywego obrazu miłości. Autentyczna miłość zawsze ma na uwadze rzeczywiste dobro drugiego człowieka. Prawdziwe wychowanie jest wychowaniem do wolności. W kontekście rodziny nie może więc być mowy o chęci uzależnienia dziecka od siebie, o używaniu szantażu emocjonalnego, o podkreślaniu poświęcenia rodziców z równoczesnym wymaganiem od dziecka rekompensaty. Rodzice nie mogą wystawiać swoim dzieciom rachunku, domagać się "spłaty długu” za ich poświęcenie (Błasiak, 2012, s. 341-342). Dobry rodzic dąży do tego, żeby dziecko było spełnione w swoim życiu. Zatem rodzic nie powinien wyrażać wobec dziecka własnych oczekiwań dotyczących wyboru drogi życiowej dziecka. Nie może dokonywać wyboru w imieniu dziecka, ale musi pozwolić na samodzielne poszukiwania i odczytywanie swojego powołania. Dążenie do ciągłego sterowania życiem dorosłego dziecka może być źródłem wielu bolesnych konfliktów, które mają fatalny wpływ na życie wszystkich członków rodziny (Sujak, 2009). Wszelkie utrudnianie dziecku realizacji jego możliwości, nabywania pozytywnej pewności siebie, wolności od nacisków i presji zewnętrznych świadczy o patologii rodziny (Ryś, 1998). Należy z całą mocą podkreślić, że rodzicielska zgoda na samodzielne odczytanie własnego powołania przez dziecko jest, jak to wcześniej zostało pokazane, wymogiem katechizmowym.

\section{Małżeństwo i rodzina miejscem rozwoju dorosłych i dzieci}

W świetle nauczania Kościoła Katolickiego relacja małżeńska stanowi podstawę wszelkich relacji rodzinnych. Łaska sakramentu małżeństwa uzdalnia małżonków, a z czasem również rodziców, do podejmowania kolejnych obowiązków wychowawczych (Jan Paweł II, 1981, n. 38). Warto zwrócić uwagę na to, iż zarówno małżeństwo, jak i rodzina 
mogą stać się przestrzenią rozwoju wszystkich osób uczestniczących we wzajemnych relacjach. Rozwój człowieka, jako proces „stawania się, osiągania coraz wyższego poziomu dojrzałości" (Ryś, 1998, s. 37) przebiega dzięki nawiązywaniu dobrych relacji z innymi ludźmi.

Zdaniem Janusza Homplewicza (2000) człowiek wzrasta osobowościowo w kontakcie $\mathrm{z}$ innymi, w otwarciu się na innych. Rodzina to $\mathrm{w}$ istocie najlepsze miejsce i droga ku dojrzewaniu i rośnięciu przez innych i dla innych. „Wymownym prawzorem tych międzyludzkich kontaktów jest oczywiście małżeństwo, to prawzór kontaktu partnerskiego: małżonków i rodziców, a potem ich z ich dziećmi" (tamże, s. 80). Można powiedzieć, że wszechstronny rozwój wszystkich członków rodziny umożliwia właściwe funkcjonowanie podsystemu małżeńskiego (Kozubska, 2016).

Rodzina stanowi system wzajemnych powiązań uczuciowych i oddziaływań społecznych. Każdy ma wpływ na rozwój i zmianę zachowania innych osób (Ryś, 1998). Odpowiednim wydaje się więc traktowanie rzeczywistości małżeństwa i rodziny jako przestrzeni umożliwiających rozwój wszystkich osób uczestniczących we wzajemnych relacjach. Członkowie rodziny, uczestnicząc w jej życiu, wzajemnie zaspokajają swoje potrzeby, wzajemnie się potrzebują i wzajemnie sobie pomagają (Błasiak, 2000). Ta wzajemność widoczna jest również na polu wychowania. Wymaga jednak uznania wielostronności i wielopodmiotowości wychowania. Podmiotowość każdego członka rodziny w kontekście wychowania wyraża się wówczas, kiedy każda osoba kreuje albo przyczynia się do tworzenia warunków pożądanych wychowawczo; kiedy intencjonalnie wzbudza i organizuje procesy wychowania oraz samowychowania oraz kiedy podejmuje pracę nad sobą, czyli trud samowychowania (Sowiński, 2013). W zdrowej, świadomej swego posłannictwa rodzinie, zarówno rodzice jak i dzieci stają się wzajemnie dla siebie pomocą w rozwoju osobowym. Nazywany „Papieżem Rodziny” Jan Paweł II nauczał, że „wychowanie jest (...) obdarzaniem człowieczeństwem - obdarzaniem dwustronnym. Rodzice obdarzają swym dojrzałym człowieczeństwem nowo narodzonego człowieka, a ten z kolei obdarza ich całą nowością i świeżością człowieczeństwa, które z sobą przynosi na świat" (Jan Paweł II, 1994, n.16, s.58). Wychowanie jest więc rzeczywistością międzyosobową (Kaźmierczak, 2003, s. 30). Można powiedzieć, że w rodzinie wszyscy mają wobec siebie wzajemnie obowiązek wychowywania, „rozszerzania horyzontów” (Goffi, 2001, s. 189-190). Należy podkreślić, że rodzina tworzy warunki rozwoju i wychowania dla wszystkich: zarówno dzieci, jak i dorosłych (Opozda, 2019). Zadanie wychowania potomstwa dynamizuje rozwój dorosłego, a nawet stanowi jego źródło (tamże). Wymaga bowiem dokonywania ciągłych zmian w sobie samym. W literaturze przedmiotu zwraca się uwagę na wymagania, jakie stawia samo bycie rodzicem. Są to m.in.: dyspozycyjność, gotowość i otwartość, ciągłość i codzienność oddziaływań, stałe reagowanie i towarzyszenie w rozwoju dziecka, potrzeba pracy nad sobą, budowanie wzoru osobowego i autorytetu, 
rozwijanie kompetencji interpersonalnych i cech sprzyjających lepszemu kontaktowi z dzieckiem i bardziej efektywnej transmisji wpływów wychowawczych, takich jak np. cierpliwość, refleksyjność, konsekwencja. Rodzicielstwo również aktywizuje procesy poznawcze, emocjonalne, wartościowania, motywacyjne (Opozda, 2019). Bycie rodzicem od samego początku wymaga również od małżonków przyjęcia postawy otwartości na nowe nowe życie, nowe zadania, nowe relacje, nowe zwyczaje. Etapowość życia małżeńskiego i rodzinnego wymusza na wszystkich członkach pewną elastyczność, którą można określić mianem permanentnego dążenia do równowagi z równoczesną gotowością na zmiany. Chociaż rodzina ciągle się rozwija i zmienia, to jednak wykazuje tendencję do zachowania równowagi (Łukasiewicz, Pawelec, 2012). Inaczej wygląda życie małżeństwa oczekującego na narodziny pierwszego dziecka, inaczej życie z małymi dziećmi i jeszcze inaczej życie na etapie odchodzenia dzieci $\mathrm{z}$ domu. Codzienność małżeńska i rodzinna wymusza dokonywanie zmian rozwojowych (Kozubska, 2016). Danuta Opozda 92019) stwierdza m.in.: „Podejmowana aktywność w rolach rodzinnych (głównie małżeńskich i rodzicielskich) stymuluje zachodzenie zmian progresywnych $u$ samego dorosłego. Wieloaspektowe i zróżnicowane doświadczenie, płynące $\mathrm{z}$ uczestnictwa w relacji małżeńskiej i rodzicielskiej, tworzą warunki dla rozwoju osobowego dorosłego i mają znaczący wpływ na kształtowanie jego charakteru" (tamże, s. 28). Powyższe stanowisko potwierdzają również publikacje innych autorów, którzy proponują traktowanie rodziny jako przestrzeni uczenia się dorosłych (np.: Całusińska, 2012, s. 16; Kozubska, 2016, s. 165).

\section{Podsumowanie}

Zamierzeniem autorki była rekapitulacja nauczania Kościoła dotyczącego najważniejszych przestrzeni, w których odbywa się rozwój człowieka oraz analiza wybranych wyzwań związanych z rodzicielstwem. Na podstawie dokonanej analizy zarówno materiałów źródłowych, jak i opracowań, można stwierdzić, że wejście na drogę sakramentalnego małżeństwa łączy się z konkretnymi zobowiązaniami zarówno małżonków wobec siebie wzajemnie, jak i wobec będących owocem ich związku dzieci. Poznanie, zrozumienie, akceptacja i uznanie istoty katolickiego małżeństwa i rodziny stanowi punkt wyjścia wszelkich działań zmierzających do uczynienia swojego życia spójnym i prawdziwym. Konieczne wydaje się również spokojne, aczkolwiek niepozbawione emocji, przyjmowanie kolejnych etapów życia małżeńskiego i rodzinnego jako zmian będących szansą na nowe: na własny rozwój oraz na rozwój osobowy wszystkich członków rodziny. Dorastanie i dorosłość dziecka stanowi jedno z wyzwań stojących przed rodzicami. W tym kontekście szczególnie ważna wydaje się stała dbałość o przyjmowanie właściwej perspektywy relacji wewnątrzrodzinnych. Uczynienie sakramentalnego małżeństwa 
fundamentem rodziny wydaje się skutecznym zabezpieczeniem możliwości rozwoju wszystkich członków rodziny.

Zaprezentowanie w artykule analizy dotyczące nauczania Kościoła Katolickiego o małżeństwie i rodzinie oraz odniesienie wybranych wyzwań związanych z rodzicielstwem nie aspiruje do miana wywodu w pełni wyczerpującego temat. Może jednak stanowić przyczynek do podjęcia dalszych rozważań.

\section{Bibliografia:}

Adamski, F. (2002). Rodzina. Wymiar społeczno-kulturowy, Kraków: Wydawnictwo Uniwersytetu Jagiellońskiego.

Aszkiełowicz, A. (2012). Małżeństwo i jego jakość w narracjach szczęśliwych par, (w:) A. Ładyżyński (red.), Pedagogika rodziny - in statu nascendi czy uznana subdyscyplina?, 167-183, Wrocław: Oficyna Wydawnicza ATUT.

Augustyn, J. (2001). Sakrament matżeństwa. Mały poradnik dla narzeczonych i młodych matżonków, Kraków: Wydawnictwo „M".

Bełch, K. (2020). Katolicka nauka społeczna. Podręcznik dla studentów teologii i nauk społecznych, Sandomierz: Wydawnictwo Diecezjalne i Drukarnia w Sandomierzu.

Błasiak, A. (2000). Dom rodzinny i szkoła - środowiska współkształtujące osobowość dziecka, (w:) W. Kubik (red.), Rodzina. Szkoła. Kościót, 7-29, Kraków: Wydawnictwo WAM.

Błasiak, A. (2012). Obszary, możliwości i potrzeby pedagogicznego wspomagania rodziny w dzisiejszej rzeczywistości, (w:) M. Duda, A. Świerczek (red.), Dokąd zmierzasz wspótczesna rodzino?, 317-347, Kraków: Wydawnictwo św. Stanisława BM Archidiecezji Krakowskiej.

Braun-Gałkowska, M. (2009). Rozwój miłości w małżeństwie, (w:) F. Adamski (red.), Miłość. Małżeństwo. Rodzina, 139-150, Kraków: Petrus.

Całusińska, M. (2012). Trening umiejętności wychowazwczych. Dla rodziców i specjalistów, Sopot: GWP.

Deklaracja o wychowaniu chrześcijańskim Gravissimum educationis, (1967). Sobór Watykański II. Konstytucje. Dekrety. Deklaracje, 313-324, Poznań: Pallottinum.

Derdziuk, A. (2008). Wychowawcza rola rodziny w rozpoznawaniu powołania, (w:) K. Jeżyna, T. Zadykowicz (red.), Wychowanie w rodzinie chrześcijańskiej. W 25. Rocznice adhortacji apostolskiej Jana Pawła II "Familiaris consortio". Przestanie moralne Kościoła, 153-166, Lublin: Wydawnictwo KUL.

Drążek, Cz. (2009). Sakrament małżeństwa, (w:) F. Adamski (red.), Miłość. Małżeństwo. Rodzina, 73-120, Kraków: Petrus. 
Franciszek. (2016). Posynodalna adhortacja apostolska Amoris laetitia. O miłości w rodzinie, za: http://www.poradnictwo.gda.pl/images/media/pliki_pdf/AmorisLaetitia.pdf (dostęp: 17.12.2020r.).

Goffi, T. (2001). Duchowość małżeńska, Kraków: Wydawnictwo WAM-Księża Jezuici.

Grześkowiak, J. (1993). Misterium matżeństwa. Sakrament matżeństwa jako symbol przymierza Boga z ludźmi, Poznań: Hlondianum.

Homplewicz, J. (2000). Pedagogika rodziny. Zarys wykładów na podyplomowym studium prorodzinnym, Rzeszów: Poligrafia Wyższego Seminarium Duchownego w Rzeszowie.

Jan Paweł II (1981). Adhortacja Apostolska Familiaris consortio. O zadaniach rodziny chrześcijańskiej w świecie wspótczesnym, Katowice: Drukarnia Diecezjalna.

Jan Paweł II (1998). List do Rodzin Ojca Świętego Jana Pawła II, Wrocław: TUM.

Jeżyna, K. (2008). Dziecko wartością rodziny, narodu i Kościoła, (w:) K. Jeżyna, T. Zadykowicz (red.), Wychowanie w rodzinie chrześcijańskiej. W 25. Rocznice adhortacji apostolskiej Jana Pawła II "Familiaris consortio”. Przesłanie moralne Kościoła, 117-152, Lublin: Wydawnictwo KUL.

Katechizm Kościoła Katolickiego, (1994). Poznań: Pallottinum.

Kaźmierczak, P. (2003). Personalistyczna koncepcja wychowania w nauczaniu Jana Pawła II, Kraków: Wyższa Szkołą Filozoficzno-Pedagogiczna "IGNATIANUM”, Wydawnictwo WAM.

Kongregacja Nauki Wiary, Instrukcja o szacunku dla rodzącego się życia ludzkiego i o godności jego przekazywania. Donum vitae, 22.02.1987, za: https://opoka.org.pl/biblioteka/W/WR/kongregacje/kdwiary/zbior/t_2_19.html (dostęp dnia: 15.10.2020r.)

Konstytucja duszpasterska o Kościele w świecie współczesnym Gaudium et spes, (1967). Sobór Watykański II. Konstytucje. Dekrety. Deklaracje, 537-620, Poznań: Pallottinum.

Kozubska, A. (2016). Odgrywanie roli rodzica jako przestrzeń uczenia się dorosłych, (w:) A. M. Kola, P. Kostyła, H. Solarczyk-Szwec (red.), Wychowanie jednostki i wspólnoty do wartościowego życia, t. 1, 163-178, Torun: Wydawnictwo Naukowe UMK. Łukasiewicz, J., Pawelec M. (2012). Kryzys wartości w wieku średniej dorosłości w kontekście etapów życia rodzinnego, (w:) M. Jeziorański, D. Opozda, A. Rynio (red.), Rodzina przestrzenia rozwoju osoby. Perspektywa pedagogiczna, 91-105, Lublin: Towarzystwo Naukowe Katolickiego Uniwersytetu Lubelskiego Jana Pawła II.

Łużyński, W. (2008). Struktury pośrednie pomiędzy jednostka ludzka a państwem w nauczaniu społecznym Kościoła, Torun: Wydawnictwo Naukowe Uniwersytetu Mikołaja Kopernika.

Majdański, W. (2001). Wspólnota życia i miłości. Zamyst Boży o małżeństwie i rodzinie, Łomianki: Fundacja Pomoc Rodzinie. 
Mariański, J. (2009). Katolicki model małżeństwa i rodziny i jego akceptacja w świadomości Polaków, (w:) M. Szyszka (red.), Społeczeństwo, przestrzeń, rodzina: księga jubileuszowa dedykowana Profesorowi Piotrowi Kryczce, 243-258, Lublin: Wydawnictwo KUL.

Meissner, K. (2017). Płciowość człowieka w kontekście wychowania osoby ludzkiej, Poznań: Inicjatywa Wydawnicza „Jerozolima”.

Obrzędy sakramentu małżeństwa dostosowane do zwyczajów diecezji polskich (1996). Katowice: Księgarnia Św. Jacka.

Opozda, D. (2012). Pedagogiczna wielowymiarowość rozwoju osób w rodzinie, (w:) M. Jeziorański, D. Opozda, A. Rynio (red.), Rodzina przestrzenia rozwoju osoby. Perspektywa pedagogiczna, 11-31, Lublin: Towarzystwo Naukowe Katolickiego Uniwersytetu Lubelskiego Jana Pawła II.

Opozda, D. (2019). Wychowawcza funkcja rodziny, (w:) D. Opozda, M. Parzyszek, Wychowanie $w$ rodzinie $w$ wybranych zagadnieniach pedagogicznych, 11-30, Lublin: Towarzystwo Naukowe Katolickiego Uniwersytetu Lubelskiego Jana Pawła II.

Paweł VI, (1968). Encyklika Humanae vitae. O zasadach moralnych w dziedzinie przekazywania życia ludzkiego, za:

https:/ /opoka.org.pl/biblioteka/W/WP/pawel_vi/encykliki/humane.html (dostęp: 17.12.2020r.).

Pismo Święte Starego i Nowego Testamentu. W przekładzie z języków oryginalnych, (2012). Poznań: Wydawnictwo Pallottinum.

Półtawska, W. (2009). Dziecko owocem miłości, (w:) F. Adamski (red.), Miłość. Małżeństwo. Rodzina, 223-251, Kraków: Petrus.

Półtawska, W. (2018). Genealogia divina. Boże pochodzenie człowieka, Częstochowa: Święty Paweł.

Ryś, M. (1998). Rola rodziny w przygotowaniu dzieci i młodzieży do życia w małżeństwie i rodzinie, Studia nad Rodzina, 2/1 (2), 33-45.

Ryś, M. (2011). Wychowanie do miłości, (w:) F. Adamski (red.), Wychowanie osobowe, 164-181, Kraków: Petrus.

Skrzypczak, R. (2018). Miłość warta obraczek. Jak zbudować małżeństwo na całe życie, Gliwice: Fundacja Instytut Globalizacji.

Sowiński, A. J. (2013). Szkice do teorii wychowania kreatywnego, Kraków: Impuls.

Sujak, E. (2009). Konflikty i kryzysy w życiu rodzinnym - sposoby ich rozwiązywania, (w:) F. Adamski (red.), Miłość. Małżeństwo. Rodzina, 269-296, Kraków: Petrus.

Sztychmiler, R. (1999). Małżeństwo, (w:) E. Ozorowski (red.), Stownik matżeństwa i rodziny, 223-224, Warszawa-Łomianki: Fundacja Pomoc Rodzinie.

Wilk, J. (2016). Pedagogika rodziny, Lublin: Episteme.

Zwoliński, A. (2004). Społeczny wymiar życia rodzinnego, (w:) T. Borutka, J. Mazur,

A. Zwoliński, Katolicka nauka społeczna, 181-196, Częstochowa: Paulinianum. 